\title{
DINAMIKA HISTORIS BARAT-ISLAM: MISPERSEPSI, PRASANGKA, DAN KONFLIK
}

\author{
Syahirul Alim \\ Institut PTIQ Jakarta, Indonesia \\ Email: syahirulalm@uinjkt.ac.id
}

\begin{abstract}
Absract. The historical dynamics of the West-Islam always depicted as a phenomenon of misperception, antipathy, and conflicts that have been going on since the 12th century. The events of the Crusades and the spirit of reconquest of areas once occupied by Islam, leaving a bad-trail imprint in almost all perspectives of Western society towards Islam. Western antipathy was shown through negative sentiments, such as the term "saracen" to Muslim troops and the title of "Moor" which is still used by Western elites when they invaded and control various Muslim-majority areas. The heritage of Islamic civilization for the progress of the Western World is only valued to the extent of the "threat" about the revival of the glory of Islamic civilization that had ruled the world for about 7 centuries. The efforts of some Western scholars who are more objective perceived in understanding Islam, apparently are not so influential and Islam was still misunderstood by the West, even Islamophobia was becoming a phenomenon that strengthens as a form of Western fear of Islam. This paper seeks to portray the historical dynamics of West-Islam from various perspectives descriptively-analysis through a bistorical approach. Historical awareness is needed, so that too excessive and baseless assessments of anything should be avoided, because history was a series of past events that can provide information in the present, functioning as a frame of knowledge in placing a reality in a fitting and objective manner.
\end{abstract}

Keywords: Islam; Barat; Orientalisme; Islamofobia; Barat-Islam.

Abstrak. Dinamika historis Barat-Islam selalu menggambarkan fenomena mispersepsi, antipati, bahkan konflik yang telah berjalan sejak abad ke-12. Peristiwa Perang Salib dan semangat penaklukan kembali wilayah-wilayah yang pernah dikuasai Islam oleh pasukan Salib, meninggalkan jejak buruk dalam hampir seluruh perspektif masyarakat Barat terhadap Islam. Antipati Barat ditunjukkan melalui sentimen negatif, seperti sebutan "saracen" kepada pasukan Muslim dan gelar orang "Moor" yang tetap dipakai kalangan elit Barat ketika mereka melakukan invasi dan penguasaan atas berbagai wilayah berpenduduk mayoritas Muslim. Warisan peradaban Islam bagi kemajuan Dunia Barat hanya dihargai sebatas "ancaman" tentang kebangkitan kembali kejayaan peradaban Islam yang pernah menguasai dunia selama kurang lebih 7 abad. Upaya beberapa sarjana Barat yang lebih objektif dalam memahami Islam, ternyata tidak begitu berpengaruh dan Islam tetap disalahpahami oleh Barat, bahkan Islamofobia menjadi fenomena yang menguat sebagai bentuk ketakutan Barat terhadap Islam. Tulisan ini berupaya memotret dinamika historis Barat-Islam dari berbagai perspektif secara deskriptif-analisis melalui pendekatan historis. Kesadaran historis diperlukan, sehingga penilaian yang terlampau berlebihan dan tanpa dasar terhadap hal apapun seharusnya dapat dihindari, sebab sejarah merupakan rangkaian peristiwa masa lalu yang dapat memberikan informasi pada masa kini, berfungs sebagai bingkai pengetahuan dalam menempatkan sebuah realitas secara pas dan objektif.

Kata Kunci: Islam; Barat; Orientalisme; Islamofobia; Barat-Islam.

Permalink/DOI: https://doi.org//10.15408/mimbar.v37i1.16118 


\section{Pendahuluan}

Islam dan Barat, atau terkadang dikenal dengan istilah "Islam" dan "Eropa" merupakan dua istilah yang asimetris. Yang disebut pertama jelas merujuk pada istilah "agama" dengan segala perangkat teologis dan praksisnya, yang lain justru lebih berkonotasi "wilayah" (region) atau geografis, satu sisi dari belahan lain dunia. "Barat" dalam pengertian ini tampak memperlihatkan suatu tatanan sosial- politik yang selalu dikesankan memiliki suatu peradaban lebih maju — terutama setelah abad Pertengahanyang berhadapan langsung dengan wilayah bagian Timur-yang dipandang Barat sebagai bagian wilayah yang belum maju atau tercerahkan. Menyebut istilah "Barat" dan "Islam" seolah sedang mempertentangkan dua peradaban: Barat sebagai Dunia Kriten (Christendom), sedang lainnya dipandang sebagai sebuah tatanan peradaban yang dikuasai oleh Islam (Islamdom). Dari istilah yang muncul ini saja terasa "dikotomistik" bahkan tetap dirasakan hingga saat ini. Barat dan Islam selalu saja "berbeda" dan tampak saling bersaing hampir sepanjang sejarah peradaban manusia.

Bernard Lewis dalam Islam and The West, juga memperlihatkan bagaimana keduanya ini (Barat dan Islam) secara tidak langsung merujuk pada istilah dua perbedaan agama yang saling berkompetisi di dunia, yaitu Kristen dan Islam. Perbedaan ini terletak pada istilah "religion" (agama) yang dipahami oleh masyarakat Muslim, tidaklah identik dengan pengertian "agama" dalam masyarakat Barat- Kristen. Istilah "religion" umumnya dipergunakan masyarakat Eropa-baik di Barat maupun Timur-mengambil dari akar kata bahasa Latin, "religio", suatu istilah yang dipergunakan masyarakat pra-Kristen untuk menyebut bentuk kultus dan ritus masyarakat paganis Roma yang "dikristenisasi” oleh Santo Jerome sebagaimana disebut dalam terjemahan Injil bahasa latinnya (Bernard Lewis, 1993). Sedangkan istilah "agama" dalam pemahaman seorang Muslim merujuk pada bahasa Arab "diin" yang dalam banyak hal justru lebih memiliki konotasi hukum daripada bentuk ritus tertentu.

Dinamika historis Barat dan Islam menemukan tempatnya dalam berbagai aspek, baik agama maupun politik, terutama terkait erat dengan semangat Perang Salib (Crusade) yang cenderung dihadapkan pada istilah padanannya dalam Islam, yaitu "Jihad" - meskipun sebenarnya tidak tepat.

Dalam tradisi Islam, "jihad” tentu saja tidak selalu bermakna "perang”; adakalanya ia berkonotasi "kemampuan" (thaqah) atau "jahd" yang berarti "rintangan" (masyaqqah). Berbeda dengan "Perang Suci” yang melekat dalam istilah "crusade". Itulah sebabnya John L. Esposito ketika membahas tentang "Jihad dan Perjuangan Demi Islam" mengawali uraiannya dengan memaparkan dua pertanyaan besar ini (Brown \& Esposito, 2002).

Aspek politik tampaknya lebih memberi penekanan atas semangat Barat yang harus merebut kembali wilayah-wilayah yang diklaim sebagai milik mereka yang dahulunya sempat menjadi wilayah kekuasaan Islam. Konsekuensi ini pada akhirnya mengerucut hanya pada aspek "agama", sebab agama merupakan unsur pokok dari suatu peradaban. Oleh karena itu, wajar jika Lewis menyebut peradaban Barat dengan sebutan "Christian Civilization" yang secara diametral saling berhadapan dengan apa yang disebut peradaban Islam. Dalam artikelnya yang cukup kontroversial, "The Roots of Muslim Rage" (1990), ia seakan telah mempersiapkan dan menentukan siapa "musuh baru" Barat pasca Perang Dingin. Huntington kemudian mengadopsi dan memperluas ide Lewis, melalui suatu tesisnya, dimana dunia dalam skala politik global, menurutnya, akan di dominasi oleh konflik antarperadaban, yaitu Barat dan Islam (Husaini, 2017). 
Realitas hubungan Barat-Islam sejauh ini lebih banyak memperlihatkan suatu kenyataan yang kurang berimbang: mispersepsi, prasangka, dan tak jarang konflik, daripada membangun suatu upaya penyadaran koeksistensial bahwa Barat dan Islam seharusnya berjalan beriringan demi sebuah cita-cita peradaban yang lebih mengedepankan nilai-nilai kemanusiaan. Upaya-upaya yang digagas untuk mengikis persepsi sejarah masing-masing yang saling kontradiktif melalui dialog, tetap saja belum merepresentasikan aspek "persamaan" namun lebih banyak menunjukkan "perbedaan", dimana Barat tetap merasa superior secara politik dan peradaban, sedangkan "Islam" dan wilayah-wilayah non- Barat lainnya tetap "inferior" dan seringkali dicurigai sebagai pihak-pihak yang akan mengganggu dominasi kekuasaan Barat. Sekalipun terdapat realitas pasang-surut relasi- relasi Barat-Islam, namun secara umum, yang ditakuti oleh Barat hanyalah Islam bukan ideologi keagamaan tertentu atau kekuatan politik lainnya.

Peradaban, pada akhirnya menempati posisi yang paling berpengaruh dalam konteks hubungan Islam-Barat, sebab bagaimanapun, Islam dalam keumuman pandangan Barat, merupakan satu "peradaban lain" yang juga pernah eksis dan memiliki pengaruh yang sangat besar selama berabad-abad. Padahal, apa yang disebut sebagai peradaban Arab-Islam, tentu saja dalam beragam bentuknya hampir tak pernah berdiri sendiri, tetapi justru seringkali mengadopsi peradaban yang berasal dari Latin/Kristen-Barat. Banyak sekali interaksi lintas-budaya antara keduanya yang telah mengambil tempatnya dalam rentang sejarah cukup panjang hingga sampai pada era peradaban milenium ini. Itulah sebabnya, kenapa "Islam" dan bukan entitas lainnya yang selanjutnya dianggap Barat sebagai "ancaman" bagi peradaban mereka.

Citra Faktor paling dominan dalam membangun citra Barat-Islam kontemporer adalah pengaruh langsung dari Islam politik, atau yang belakangan lebih populer merujuk kepada apa yang disebut sebagai "fundamentalisme Islam" (Esposito, 1999). Citra Barat terhadap Islam tentu saja memiliki pijakan historisnya tersendiri, bahkan telah dimulai sejak berkobarnya Perang Salib pada abad ke-11 dan ke-12, dimana telah mengobarkan semangat fanatisme keagamaan yang diarahkan secara langsung untuk berperang melawan kaum Saracen. Kaum Saracen dipandang sebagai orang-orang buta dan bodoh yang menyembah Muhammad. Selain itu, Muhammad sendiri dianggap ahli sihir atau malah iblis. Muhammad dalam Bahasa Inggris dipanggil "Mahound". Ini adalah pengotoran atas namanya yang sesungguhnya (Watt et al., 1997).

Padahal, sejarah telah mencatat sebelumnya, selama berabad-abad, dimana keduanya (Barat/Kristen dan Islam) telah saling berjalan beriringan tanpa masing-masing merasakan adanya ancaman. Islam sebagai sebuahperadaban, tidak pernah "mendominasi" secara kultural maupun politik. Dalam konteks yang kurang lebih sama, Karen Amstrong menyatakan bahwa sekalipun Islam pernah mencapai kebangkitannya pada abad ke-7 dan ke-8, tetapi umat Islam tidak pernah mencapai hegemoni dunia dan tidak membangun peradaban baru seperti yang dilakukan Eropa pada abad ke-16 (Amstrong, 2004). Hal ini sebagaimana pernah diakui oleh orang-orang Kristen Mozarab ketika membangun peradaban di Spanyol Islam, yang dianggap milik mereka sendiri secara bersama- sama.

Perang Salib dan "penaklukan kembali” (Reconquista) menjadi satu-satunya bagian dari sejarah; dan hampir selama periode ini telah memupuk rasa kebencian Barat terhadap Islam. Terdapat semangat yang terus menerus dialirkan melalui peristiwa tersebut, melalui sudut pandang konflik dalam banyak 
hal, untuk mengembalikan Eropa menjadi satu tradisi yang dominan. Selama masa Renaisans, cara pandang terhadap Islam seringkali tumpang- tindih, antara kesan yang menyegarkan karena Islam dengan berbagai aktivismenya memecut semangat bangsa Eropa dalam ilmu pengetahuan, tetapi disisi lain, "ancaman" Islam tetap masih dominan dalam sebagian besar cara pandang orang-orang Barat. Kendatipun, selama abad ke-15 sampai abad ke-17, mispersepsi terhadap Islam tampak samar, namun sikap Barat yang merendahkan Islam tetap masih mendominasi. Istilah "Saracen" misalnya, diperhalus menjadi "Moor" atau "Turk".

Sebutan "Moor" kepada Muslim terjadi setelah Granada jatuh ke tangan pasukan Salib dalam suatu peritiwa Inquisition (mahkamah Katolik) pada 1492. Seluruh orang Muslim yang masih tinggal di wilayah itu setelah Granada jatuh dinamai "Moriscos" (sebutan Spanyol untuk orang-orang "Moor" atau "Habsyi kecil”) (HITTI, Philip K; Hutagalung, Usuludin; Sihombing, 1953).

Islam mulai agak dipahami oleh mereka secara lebih baik selama abad-abad ini dan aktivitas perdagangan serta militer tampak menunjukkan peningkatannya, terutama di kawasan Mediterania. Memang, pengaruh atas berbagai kemajuan dalam kebudayaan masyarakat Eropa sangat memungkinkan untuk merubah seluruh cara pandang mereka, paling tidak telah dilakukan sebagian elitnya terhadap Islam (David R Blanks \& Michael Frassetto (ed.), 1999).

Dikotomisasi Barat-Islam memang digulirkan untuk berbagai tujuan-tujuan politis, terutama dilakukan para penulis Eropa-Kristen yang mempropagandakan sejarah yang tidak berimbang mengenai Islam. Sebutan "Saracen" terhadap masyarakat Muslim telah membentuk stereotipe, dimana Islam digambarkan sebagai "kelompok agama" yang menyimpang (beretic) dan bertentangan dengan imanKristen. Kesan negatif tentang Islam ini terus disebarluaskan oleh penulis-penulis Barat di masa itu, seperti Guibert of Nogent, Peter the Venerable, atau Robert of Ketton (Michael Frasetto, 1999). Peter bahkan sukses menulis suatu ringkasan ajaran Islam-berdasarkan terjemahan Al-Qu'an berbahasa Latin oleh Robert-(Summa totius haeresis Saracenorum) dan suatu penolakan atasnya (Liber contra sectam sive haeresim Saracenorum). Sekalipun kedua karya awal tentang citra Islam ini terbebas dari kesalahankesalahan prasangka Perang Salib, namun pada masanya, karya itupun tidak banyak membentuk citra baru mengenai Islam di Eropa (Watt et al., 1997). Citra para sarjana Barat Abad Pertengahan terhadap Islam memang memiliki banyak perbedaan, terutama dengan karya- karya selanjutnya yang ditulis para sarjana Barat modern. Namun bagaimanapun, citra negatif terhadap Islam telah terbentuk dan sedemikian melekat dalam benak masyarakat Eropa sejak Abad Pertengahan-terlepas atau tidak dengan realitas Perang Salib_-dimana Islam senantiasa didiskreditkan secara teologis- historis, bahkan sebagai agama, Islam dianggap bertentangan langsung dengan iman Kristen hampir secara keseluruhan.

Selama hampir beberapa abad, para penulis kronik Perang Salib dalam sejarah Latin-Eropa, selalu menempatkan "Saracen" sebagai musuh mereka dan secara sangat jelas membangkitkan semangat kebencian terhadap Islam. "Saracen", bagi Kristen merupakan penganut agama pagan yang harus disadarkan, dan serangkaian kemenangan pasukan Salib dicitrakan sebagai bentuk perlawanan dan pemberangusan atas unsur-unsur paganisme. Para penulis kronik Perang Salib membuat tokoh-tokoh tertentu yang dijadikan pahlawan, seperti Jupiter, Apollo, dan juga "Mahomet". Namun, mereka justru membangun karakteristik musuh utamanya dengan sebutan "Mabummicolae" suatu istilah bagi "para penyembah Muhammad" (Muhammad-worshippers) yang hampir tak pernah lagi menyebutnya dengan istilah lain, seperti "Islam" atau kaum "Muslim" (Tolan, 1999). 
Selama beberapa abad, Islam selalu dipahami secara melenceng oleh para penulis Eropa-Barat. Beberapa diantaranya seringkali menyimpan alasan yang cenderung apologetik, untuk sekadar mempertahankan dan membela aspek iman Kristen dari keberatan dan kritik atasnya; namun disisi lain, terdapat sikap apologis yang kerap muncul disaat mereka harus mengidentifikasi diri mereka melalui berbagai warisan klasik mereka sendiri yang berakar pada peradaban Yunani dan Romawi, dimana Islam sudah terlebih dahulu terlibat dalam kedua peradaban besar itu. Mereka (orang-orang Eropa-Barat) selalu ingin membedakan identitas diri mereka dengan Islam, sekalipun mereka menyadari, bahwa utang mereka terhadap sumbangan ilmu pengetahuan dan filsafat Arab yang sedemikian melimpah, sulit dihindarkan, bahkan sangat mustahil jika tanpa disertai tindakan yang positif. Perkenalan dunia Barat dengan pemikiran filsafat klasik Plato dan Aristoteles, justru mengambilnya melalui karya filosof Muslim Ibnu Sina, bahkan ketika pengaruh filsafat Aristoteles semakin meningkat di Barat, karya-karya Ibnu Rusyd tetap merupakan rujukan paling penting yang dipakai oleh kebanyakan para pemikir Barat.

Suatu fakta sejarah yang cukup penting, dimana bangsa Arab menduduki Spanyol hampir selama 7 abad yang berhasil membuat matarantai ilmu pengetahuan yang menghubungkan antara Barat-Latin dengan filsafat Yunani, dalam bentuk yang digubah oleh mereka dan para sarjana Islam Timur. Hitti menyebut bahwa sepanjang abad ke-8 hingga abad ke-13, bangsa-bangsa yang berbahasa Arablah pendukung utama dari seluruh kebudayaan dan peradaban di seluruh dunia yang kemudian mengantarkan ilmu pengetahuan dan filsafat yang memicu Renaisans Eropa-Barat (HITTI, Philip K; Hutagalung, Usuludin; Sihombing, 1953) Cordoba menjadi pusat kehidupan intelektual Islam yang sangat pesat, terutama dalam hal filsafat dan teologi yang dikembangkan oleh para filosof dan pemikir Muslim. Hubungan antara orang-orang Islam dan Kristen tidak terbatas pada bidang perdagangan saja. Kebudayaan Islam mempunyai cukup daya tarik untuk memikat budi yang paling tajam di kalangan umat Kristen. Beberapa karya yang ditulis ilmuwan Muslim diterjemahkan secara selektif dan ini atas perintah langsung para uskup setelah Toledo direbut kembali dari kekuasaan Islam pada tahun 1085 (Beck \& Kaptein, 1988). Paling tidak, terdapat dua nama filosof Muslim, Avicenna (Ibnu Sina) dan Averroes (Ibnu Rusyd), yang tampil dalam pengaruhnya yang paling kuat terhadap pemikiran Kristen abad Pertengahan.

Citra objektif mengenai Islam dalam pandangan sarjana Barat kontemporer, pernah ditulis oleh Norman Daniel dalam karyanya Islam and the West: The Making of an Image (1960). Menurutnya, hal mengenai citra negatif Barat terhadap Islam secara terus menerus telah ada sejak abad XII dan sama sekali hampir tak pernah mengalami perubahan. Di dalam buku itu, Daniel membicarakan bagaimana gambaran tentang Islam yang berasal dari sumber-sumber Eropa antara tahun 1100 dan 1350 dan sejak saat itu tidak mengalami perubahan penting apapun. Sebelum abad ke-12, hampir tidak ada hubungan antara Eropa Barat dan Dunia Islam serta daerah-daerah dimana berbagai hubungan mungkin terjadi, seperti di kawasan kekhalifahan Cordoba. Hubungan spiritual antara berbagai kelompok agama sama sekali atau hampir tidak ada. Menurut Daniel, gambaran Barat tentang Islam muncul pada masa Perang Salib dan sejak saat itu sulit dan hanya sedikit mengalami perubahan (Steenbrink et al., 1995).

Sekalipun karya Daniel ini cukup menjelaskan secara lebih objektif dan berimbang apa yang menjadi persoalan dalam hubungan Islam-Barat, namun tidak berarti bahwa tidak mungkin untuk mengkaji dengan jujur sebuah tradisi religius dalam pandangan lain. Hodgson dengan agak skeptis mengungkapkan hal ini, sekalipun ia berupaya untuk mempertahankan dimana pra-komitmen ilmiah 
para sarjana Barat yang melakukan kajian atas Islam, secara eksplisit cukup signifikan dalam mempengaruhi kesetiaan kultur mereka terhadap budayanya. Tentang pra-komitmen ilmiah dan kesadaran kultural dalam konteks Islam-Barat, ia menulis:

"Kita pada dasarnya adalah manusia dan hanya kemudian menjadi partisipan dalam tradisi ini dan itu...dimana atau kapan kita membandingkan Barat dan dunia Islam secara umum dan agama Islam dan Kristen secara khusus, kesadaran yang seperti itu sangatlah esensial. Telah ada kecenderungan diantara orangorang Kristen yang mau mengakui keabsahan spiritual Islam, untuk melibat Islam kurang lebih seperti versi yang terpenggal dari kebenaran Kristen... demikian juga kaum Muslimin, telah secara historis melihat agama Kristen sebagai Islam yang terpenggal atau ternoda" (Hodgson, 2012).

Sulit rasanya untuk menjelaskan, kapan dan bagaimana dunia ini terbelah kedalam wilayah "Barat" yang di dominasi Kristen dan "Timur" yang di dominasi Islam. Namun yang pasti beragam prasangka atau mispersepsi antarmasyarakat bangsa di berbagai belahan dunia telah membawa serta mentalkognitif mereka untuk sama-sama membangun persepsi sejarahnya sendiri-sendiri. Barat, yang secara peradaban lebih diunggulkan, telah menyebar luaskan cita-cita pencerahannya kepada bagian "dunia lain" melalui aktivitas imperialisme dan kolonialisme. Proyek ini pada akhirnya mendesakkan kecenderungan erosentrisme kedalam cara berpikir dan pola hidup yang secara tak terelakkan mereduksi nilai-nilai dan tradisi genuine masyarakat bangsa-bangsa tersebut (Tamara \& Taher, 1996).

Dikotomi Islam/Barat sepertinya baru dimulai sebagai akibat persepsi ganda yang muncul setelah Perang Dingin sehingga membelah dunia menjadi bagian Timur dan Barat. Dalam mencari sebuah bentuk kekuatan politik baru yang saling berlawanan sejak 1980- an, Barat lebih memilih untuk berkonfrontasi dengan Islam melalui pertimbangan isu-isu budaya sebagi salah satu pemicu konfliknya (Muñoz, 1999). Isu-isu budaya tampaknya berhasil membangun suatu jembatan antara "kita" dan "mereka", sehingga kebudayaan dalam hal ini seringkali dianggap sebagai sumber jati diri yang harus selalu diperjuangkan. Istilah "kebudayaan" tampaknya ingin menggeser sejarah kelam kolonialisme kedalam bentuk imperialisme baru Dunia Barat. Dengan nada sinis, Edward Said menyebutnya sebagai "zaman imperium" sekalipun telah roboh seiring berakhirnya struktur kolonial pasca Perang Dunia Kedua, namun dalam satu atau lain cara masih tetap menyebarkan pengaruh budaya yang sangat besar di masa kini (Edward W Said et al., 1995).

Akar historis dari rangkaian dinamika "pasang-surut" hubungan Barat-Islam seringkali diwarnai mispersepsi, prasangka, dan konflik dan hal ini benar-benar dipengaruhi faktor prakomitmen ilmiahmeminjam istilah Hodgson-dimana keputusan historis tidak dapat sepenuhnya dilepaskan dari prakomitmen dasar para penyelidiknya. Menurut Hodgson, semakin mendalam mereka dalam berbagai penelitian sejarah, semakin besar juga kemungkinannya untuk berakar dalam salah satu tradisi kultural yang utama untuk mencapai komitmen akhir yang menyeluruh. Mereka yang kemudian disebut kaum "Westernis" memiliki komitmen dan kesetiaan tertinggi kepada apa yang mereka sebut sebagai kebudayaan Barat. Tradisi Kristen tentu saja begitu sentral bagi kebudayaan Barat, sekalipun banyak yang menolak klaim kesetiaan pada Kristen itu sendiri (Hodgson, 2012). Hubungan Barat-Islam, pada akhirnya, memang tak pernah berada pada arus tensi yang normal, dimana-mana selalu saja ada kecurigaan dan prasangka yang pada tahap tertentu dapat menimbulkan ketegangan bahkan perang (seperti peristiwa Perang Teluk) yang juga mengambil tempatnya menurut versi kalangan Dunia Islam sebagai "perang peradaban" antara Islam dan Barat (Huntington, 1993). 
Perang Salib, lagi-lagi merupakan faktor utama yang mengiringi fenomena hostoris soal persaingan ideologis dan konflik politis antara apa yang belakangan ini diidentifikasi sebagai Barat (Kristen) dan Islam. Sejak beberapa abad lamanya, hubungan keduanya seringkali penuh ketegangan. Keduanya bersikukuh pada "prinsip" masing-masing. Konflik di abad ke-20 antara demokrasi liberal dengan Marxis- Leninisme hanyalah sebuah fenomena hostoris yang bersifat sementara dan superfisial jika dibandingkan dengan hubungan konfliktual antara Islam dan Kristen. Suatu ketika keduanya hidup berdampingan secara damai, akan tetapi di lain waktu lebih sering terlibat dalam hubungan yang penuh persaingan, dan dalam berbagai tingkatan terlibat dalam kecamuk perang. Disisi lain, bahwa kenyataan historis dimana sejak abad VII sampai pertengah abad VIII, kekuatan-kekuatan Islam mampu mendirikan pemerintahan Islam di Afrika Utara, Iberia, Timur Tengah, Persia, dan bagian utara India. Kemudian pada akhir abad XI, orang- orang Kristen ingin kembali menguasai wilayah barat Mediterania, menyerang Sicilia, dan menaklukan Toledo (Huntington, 1993).

Keterkaitan dengan sejarah politik masa lalu, telah sedemikian kuat berpengaruh terhadap cara Barat dalam memandang Islam. Eksistensi Islam sebagai agama dunia dan kekuatan ideologis yang dianut oleh seperlima penduduk dunia, dengan vitalitas serta kekuasaannya yang terus berlanjut dari Afrika hingga Asia Tenggara, telah menimbulkan perasaan takut di kalangan masyarakat Barat akan "ancaman" Islam. Rasa takut inilah yang terus menerus memunculkan pandangan negatif terhadap Islam, sehingga muncul pengertian distortif tentang "Islam" dan kata "Muslim" di kalangan masyarakat Barat. Angan- angan Barat dipenuhi oleh citra menakutkan tentang dunia Islam, dan ini secara terus menerus mendapatkan dukungan dari media massa Barat (Putro, 1998). Respon Muslim terhadap Barat tidak semata-mata karena faktor pertentangan teologis Islam-Kristen, namun lebih kepada respon atas upaya modernisasi dan sekularisasi Barat atas yang lainnya.

\section{Islam Dan Barat Kontemporer: Hegemoni Budaya Dan Kebangkitan Agama}

Jauh sebelum dunia terbelah kedalam dikotomi Oriental/Oksidental (Timur/Barat), atau dalam konteks peradaban yang lebih ekslusif: Barat/Islam, kawasan Mediterania telah muncul sebagai pusat sejarah dunia. Pada saat ini, penggabungan bebebrapa wilayah Eropa yang perluasannya mengambil tempat di bagian Utara dan dilanjutkan oleh gelombang besar Islam politik di bagian Selatan telah membuat masing-masing wilayah ini sangat penting dalam bingkai politik internasional kontemporer. Para sejarawan umumnya terbiasa dengan pusat-pusat peradaban di kawasan Mediteranian, sebelum kejayaan Islam atau kebangkitan "Islamisme" pada masa kini. Namun, pemahaman seperti ini telah merubah pandangan Barat, ketika Islam tidak menempatkan dirinya hanya sebatas agama, mereka melihat kawasan Meditarania sebagai pesaing bagi peradaban mereka (Bassam Tibi, 2014).

Sejarah pra-modern telah menunjukkan suatu dualitas dimana dunia terbagi kedalam bagian Utara dan Selatan, dimana kawasan Mediterania sangat jelas memberikan gambaran suatu kompleksitas tentang "tatanan dunia baru", mengangkat berbagai drama dalam wujud konflik, menegangkan, dan hampir tidak berimbang. Mediterania secara keseluruhan telah membentuk bagian-bagian paling menentukan bagi keberlangsungan masa depan Eropa, baik secara demografi, ekonomi, ekologi, termasuk didalamnya perkembangan politik- militer dan di atas semuanya itu adalah isu-isu seputar sosial-budaya hingga saat ini. Arkoun hingga sampai pada suatu kesimpulan, dimana kawasan Mediterania ini telah menjadi dan bahkan masih "menjadi bagian yang paling sulit diatasi, baik 
mengenai berbagai perbedaan, identitas yang berurat-akar, peperangan yang kejam, dan kecenderungan yang destruktif (Khader, 1999).

Melalui serangkaian penaklukan atas kawasan Mediterania, pasukan Arab-Muslim kemudian merebut Eropa melalui Spanyol dan beberapa abad berikutnya, gelombang invasi pasukan Muslim menguasai wilayah Balkan di bagian Tenggara. Bassam Tibi menyebut model "penaklukan" ini dengan istilah "Islamic futubat-expansion" yang erat kaitannya dengan semangat "fathu Makkab" sebagaimana yang pernah terjadi pada masa Nabi Muhammad. Konsep yang diambil dari peristiwa "pembukaan Mekah" oleh Nabi Muhammad ini jauh dari nuansa penaklukan dengan cara-cara militeristik, namun lebih berkesan "keterbukaan" atau menunjukkan suatu fenomena atas proyek globalisasi pertama dalam sejarah dunia. Realitas sejarah ini jelas membuat beberapa pengamat meyakini, bahwa peradaban Islam dapat menjadi ancaman bagi Barat melalui bentuk Islamisasi yang mulai tampak belakangan ini. Bagaimanapun, seluruh romantisme Spanyol Islam abad Pertengahan merupakan warisan pengalaman sejarah yang sama sekali bukan model hubungan Islam- Barat, tetapi lebih kepada penyatuan Eropa itu sendiri ke dalam peradaban Mediterania yang Islam (Khader, 1999).

Islam, memiliki sejarah yang unik dalam perkembangannya, bahkan semenjak beberapa tahun setelah wafatnya Nabi Muhammad. Pergerakan pasukan Muslim ke segala penjuru yang diawali dengan penguasaan atas wilayah Syam (Levant), hingga ke Afrika Utara dan Asia Kecil, menunjukkan bahwa agama ini dapat diterima oleh seluruh ras dan etnik manusia di seluruh penjuru dunia. Mayoritas dari suatu masyarakat baru yang dibentuk oleh kekuatan Islam juga mengadopsi bahasa Arab sebagai "lingua franca" yang dipergunakan sebagai bahasa pergaulan mereka. Hanya kurang dalam dua generasi, bahasa Arab menjadi Bahasa sehari-hari, termasuk dalam konteks hukum, literatur, seni, perdagangan dan ilmu pengetahuan, mulai dari Spanyol sampai ke Iran, dan dari Tajikistan dan Bukhara hingga ke bagian Afrika Tengah. Umat Muslim telah membentuk suatu identitas masyarakat global yang sebenarnya melalui berbagai asimilasi kebudayaan dan secara bersamaan mengambil juga tradisi-tradisi lokal, yang berasal dari beragam etnik dan ras, termasuk dari masyarakat Asia, India, Cina, Persia, Eropa, Turki, Balkan, termasuk juga bangsa Arab (Ashur Shamis, 2020).

Disaat Barat mulai menancapkan hegemoninya di atas berbagai wilayah bekas koloninyaterutama puncaknya pada abad abad ke-19—respon yang berasal dari berbagai kalangan Islam justru mulai tumbuh. Kolonisasi tentu saja berdampak pada suatu kenyataan "pemaksaan" melalui upaya modernisasi yang di lakukan Barat: kehidupan finansial dan komersial dirasionalisasi dan dimasukkan ke dalam sistem Barat, dan beberapa cara "pribumi" harus menerima ide-ide dan etos modern. Konsep modernisasi seringkali menjadikan masyarakat non-Barat menjadi merasa asing dalam negerinya sendiri, sebab mereka harus berhadapan dengan aturan- aturan serba "sekuler" yang sejauh ini belum pernah sama sekali dikenal oleh mereka. Itulah sebabnya, dunia Islam seringkali menjadi bahan tertawaan dalam proses modernisasi. Umat Islam diremehkan oleh kekuatan kolonialis, yang benar-benar diilhami oleh etos-etos modern yang mengejutkan sehingga Barat hanya bisa melihatnya sebagai keterbelakangan, ketidakefisienan, fatalisme, dan korupsi masyarakat Muslim (Amstrong, 2004). Respon terhadap kenyataan modernitas dilakukan dalam berbagai intensitasnya oleh dunia Muslim, dari yang "menyesuaikan” dengan cara Barat hingga yang mempertentangkan dan bahkan menolaknya.

Kontinuitas mispersepsi dan antipati Barat terhadap Islam tetap berlangsung sekalipun banyak diantara negara-negara Muslim yang mulai membebaskan dirinya dan membentuk suatu kekuasaan 
politik yang lebih berdaulat. Mispersepsi, stereotipe, dan ketakutan yang berlebihan kepada Islam, tetap menjadi sudut pandang kekeliruan di jantung masyarakat Barat. Stereotipe masa lalu mereka terhadap "Arab" dan Islam sebagai masyarakat primitif (badui), padang pasir, unta, poligami, harem, para syekh yang "kaya minyak", ditempatkan sebagai para mullah berjenggot dengan senjata terkokang, ciri kelompak fundamentalis yang anti-Barat (Esposito, 1999). Ketakutan dan antipati Barat tidak saja menjadi santapan lezat bagi pemberitaan media dan dijadikan berita utama dalam beragam peristiwa, namun juga berakar dari cara pandang Barat yang serba sekular sebagaimana yang selama ini kita pahami.

Kontinuitas hubungan Barat-Islam ini dilihat oleh Waardenburg sebagai sesuatu yang sangat kompleks sehingga perlu mempertimbangkan berbagai hal. Ia misalnya menjelaskan bahwa pengalaman-pengalaman Barat dan persepsi mereka terhadap Islam juga dipandang beragam oleh berbagai komunitas Muslim, baik secara individu maupun kelompok. Ia mengkategorisasikan bagaimana wacana sosio-politik dan budaya Muslim dalam merespon Barat: 1) Oriental atau Oksidental/Timur-Barat sama-sama dipahami secara ekslusif, secara esensial dapat diinterpretasikan secara parsial; 2) Barat dipandang sebagai keseluruhan konsep politik sekaligus "saingan" politik; 3) Barat terkait dengan aspek modernitas sekaligus wujud masyarakat modern (berciri rasional, ilmiah, pembangun ekonomi dan keberlangsungan teknologi, dll); 4) Barat diasosiasikan dengan cara hidup yang partikularistik (dengan sedikit penghargaan atas nilai-nilai masa lalu, baik agama dan tradisi); 5) Dalam pandangan "neo- fundamentalis" (Rahman, 1984), Barat dipandang sebagai perwujudan "jabiliyah modern" yang sangat berbahaya bagi keberlangsungan kehidupan Muslim karena obsesinya yang besar terhadap aspek materialisme; suatu tempat dimana sekularisme mendominasi, suatu masyarakat yang benar-benar kehilangan aspek kebenaran tertinggi spiritualitas, norma, dan juga nilai; masyarakat yang menjadi korban hasrat, dorongan, dan nafsu materialistik; masyarakat yang "tak Bertuhan" karena yang diidolakan adalah buatan manusia.

Sarjana Muslim seperti Bassam Tibi beranggapan, bahwa kebangkitan Islam politik pasca Perang Dingin, selalu dikaitkan oleh suatu pandangan umum terhadap pengulangan sejarah masa lalu tentang dominasi peradaban Islam. Hal ini tentu saja terasa menyakitkan, karena pada akhirnya akan membentuk suatu pandangan umum yang tidak saja negatif, tetapi akan menambah kasus baru soal ektrimisme atau fanatisme agama, atau dalam pandangan yang agak positif adalah "pencerahan agama" (religious renaissance). Namun, kedua cara pandang seperti ini tetap dianggap keliru, dimana isu-isu kebangkitan peradaban dunia didasarkan atas ide baru tatanan dunia Islam, dimana jihad mengambil tempatnya kembali dalam sejarah masa kini. Tidak hanya itu, keberadaan para migran Muslim di Eropa, terkadang dikaitkan dengan kenyataan sejarah masa lalu, dimana konsep “bijrab" (migration) seiring dengan aspek "jïhad" dalam pengertian invasi atas suatu wilayah tertentu. Kekhawatiran Barat jelas terdorong oleh suatu anggapan, dimana "nilai-nilai" mereka akan "dipaksa" untuk diubah oleh nilai-nilai yang dibawa oleh para migran Muslim.

Sejarah manusia tentu saja terkait erat dengan pertukaran budaya dan peradaban, sehingga sangat tidak mungkin suatu peradaban kemudian mengisolasi dirinya tanpa mempersilahkan budaya lain meresap kedalam tata nilai sosialnya. Budaya selalu bersifat lokal, ia merupakan suatu ekspresi karya sosial mengenai makna yang pada ujungnya bersifat lokal dan tidak mungkin menjadi kerangka global. Karena alasan tersebut, maka tidak pernah ada budaya dunia, tata cara konsumsi, misalnya, tidak 
menciptakan suatu budaya dunia. Di dalam dunia Islam maupun di Barat terdapat perbedaan-perbedaan besar budaya. Budaya-budaya lokal tersebut dapat dikelompokkan ke dalam perbedaan tertentu berdasarkan landasan yang mirip dalam sikap dan cara pandang dunianya (Bassman Tibi, 1996).

Salah satu pengkritik paling keras terhadap Orientalisme yang memposisikan Barat memiliki suatu kebudayaan yang lebih tinggi, adalah Edward Said. Melalui pendekatan sastra, Said melihat terdapat kompleksitas hubungan antara masa lalu dan masa kini yang secara keseluruhan terangkum dalam wacana "imperialisme". Menurutnya, hampir tidak ada saat ini, orang Amerika Utara, Afrika, Eropa, Amerika Latin, India, Karibia, Australia yang hidup sekarang ini yang belum pernah tersentuh oleh imperium-imperium masa lalu. Abad ini tentu saja milik "imperium" Barat dan kekuatan Barat memungkinkan pusat-pusat metropolitan imperial merebut dan mengumpulkan wilayah beserta rakyatnya dalam skala yang benar-benar mencengangkan. Ingatlah, bahwa pada 1800 kekuatan Barat mengklaim 55 persen, tetapi sesungguhnya hanya menguasai kira-kira 35 persen permukaan bumi, dan bahwa menjelang 1878 proporsi itu menjadi 67 persen. Eropa kemudian menguasai total 85 persen bumi sebagai daerah koloni, protektorat, tanah jajahan, dominion, dan persemakmuran (Edward W Said et al., 1995).

Namun nampaknya, kenyataan atas imperialisme Barat yang sedemikian besar sepanjang sejarah ini, tetap saja dalam banyak hal, Barat masih menganggap Islam sebagai satu-satunya "ancaman" dibanding entitas ideologi atau politik sejenis lainnya. Prinsip umum pemikiran Orientalis adalah pengkutuban geografis yang bersifat imajinatif namun drastis yang membagi dunia menjadi dua bagian yang tidak sama, yang besar dan "berbeda" disebut "Orient" atau Timur, belahan lainnya yang juga dikenal sebagai "dunia kita" disebut "Occident" atau Barat. Itulah kenapa, J.B. Kelly mantan guru besar sejarah Kerajaan di Wisconsin, mendukung ajakan kepada Barat untuk mengambil kembali apa yang secara sah menjadi "milik kita" adalah kebencian besar- menurut Said—terhadap kebudayaan asli Islam di Asia yang semestinya "kita" kuasai (Edward William Said et al., 2002).

Westernisasi atau tepatnya "Amerikanisasi” yang setali tiga uang dengan proses hegemoni budaya melalui modernisasi, demokratisasi, dan sekularisasi, yang dijalankan Barat terhadap berbagai wilayah yang pernah menjadi koloni-koloninya, juga mendapat respon dari berbagai negara Muslim dimana terjadi pula suatu "kebangkitan Islam" (awakening of Islam). Tariq Ramadan menyebut "fenomena" ini sebagai bentuk ketakutan yang nyata Barat terhadap Islam, sebab bagaimanapun mereka menyaksikan Revolusi Iran dengan serentetan peristiwa ledakan bom, peristiwa yang sama juga terjadi di Algeria dan Palestina, termasuk pemberitaan media yang menggambarkan ibadah umat Muslim yang sedemikian massif, sampai-sampai kita sulit menjelaskannya berbagai "fenomena” tersebut. Gambaran "kekerasan" dalam Islam hampir menjadi santapan media Barat sehari-hari, bahkan sejak 1979, istilah "fanatik", "fundamentalis", dan "Islamis" hampir tidak pernah secara jelas dipahami, tetapi selalu dilekatkan kepada Islam. Kita bahkan hampir tidak pernah tahu, apakah seorang Muslim yang menjalankan salat lima kali sehari atau perempuan Muslim yang mengenakan jilbab, termasuk dalam kategori menjalankan keyakinannya atau berpotensi menjadi ekstrimis.

Sulit untuk tidak mengatakan, bahwa Islam tetap menjadi “ancaman” bagi Barat dalam banyak hal, termasuk dalam konteks agama, ekonomi, politik, dan terutama budaya. Serangkaian peristiwa historis, seperti runtuhnya Tembok Berlin dan Kehancuran ideologi komunis pada 1989 dan 1990, sekalipun telah dianggap membentuk suatu "tatanan dunia baru" bagi Barat karena berarti akhir dari 
kemenangan libarisme dan demokrasi, tetap masih menempatkan Islam sebagai kambing hitam (spacegoat) dan sekaligus ancaman peradaban bagi mereka. Abed al-Jabri mengutip sebuah artikel yang ditulis oleh Barry Buzan pada 1991 yang masih menyisakan urusan oleh apa yang disebut Buzan sebagai "benturan identitas peradaban yang saling bersaing" (the clash of rival civilizational identities) yang sangat tampak sekali yang dimaksud adalah antara Barat dan Islam (Al-Jabri, 1999). Dua tahun kemudian, tesis yang hampir sama dikukuhkan oleh Samuel Huntington dengan tampak lebih provokatif, "benturan antarperadaban" (clash of civilizations) yang kurang lebih sama, dimana masa depan politik dunia ditentukan oleh intensitas konflik antara Barat dan Islam.

Dalam konteks yang lebih baru, “ancaman” Islam tampaknya telah bergeser dalam dunia Barat menjadi sebuah istilah baru yang dinamakan "Islamofobia", suatu bentuk baru atau manifestasi dari pernyataan anti-Muslim atau anti-Islam yang hampir merupakan suatu legitimasi atau respon secara rasional terhadap kejadian 11 September 2001 (9/11). Sekalipun ada pendapat yang menyatakan bahwa Islamofobia bukan fenomena yang dipicu peristiwa $9 / 11$ saja, tetapi telah muncul jauh sejak 2001 silam. Namun yang pasti, bahwa "pasca peristiwa 11 September memberikan gambaran yang sangat kuat tentang sikap Islamofobis maupun Xenofobis yang sebelumnya tidak pernah terjadi di Barat” (Toguslu, 2014).

Tidak berlebihan jika dikatakan bahwa terlampau banyak mispersepsi terhadap Islam yang dilakukan melalui cara pandang Barat yang hampir secara keseluruhan membuat suatu anggapan "musuh" yang sangat berbahaya bagi mereka. Belum lama, dimana gambaran Islam di Asia Tenggara sebagai kawasan negara mayoritas Muslim yang paling moderat, justru mungkin pada saat ini telah banyak berubah. Peristiwa 9/11 ternyata telah mengubah cara pandang Barat secara keseluruhan terhadap Islam di seluruh dunia, termasuk terhadap citra Muslim di Indonesia. Peristiwa peledakan WTC pada 2001, telah mengubah keseluruhan cara pandang Barat terhadap Islam. Radikalisme seringkali diidentifikasi sebagai "kebangkitan agama" yang dilekatkan kepada Islam. Dalam beberapa hal, para sarjana dan peneliti seringkali terjebak dalam mengidentifikasi secara bertentangan istilahistilah yang kontradiktif yang dilekatkan kepada tipe-tipe umat Muslim, seperti "moderate" versus "ekstrimis"; atau "modern" versus "tradisionalist" yang seringkali menyebabkan mispersepsi terhadap Islam. Mutalib sampai pada kesimpulan, bahwa "itu semua merupakan pernyataan politik, bukan hasil dari satu analisis. Berbagai penjelasan mengenai kategorisasi ini telah gagal dalam memahami betapa Muslim secara identitas itu berlapis-lapis, tidak bisa hanya disederhanakan kedalam dua kategorisasi yang saling berlawanan" (Mutalib, 2006).

Sekalipun bahwa batas-batas Barat-Islam memang semakin tampak kabur karena efek globalisasi dan disisi lain, "the sick man of Europe" memang dalam keadaan sekarat, populasi Muslim bahkan selalu bertambah di seluruh dunia (Eropa mencapai hampir 13 juta jumlah Muslim dan Amerika sekitar 3,5 juta Muslim). Jauh dari pandangan bahwa Muslim berprilaku buruk atau terlibat aksi kriminalitas, mereka secara umum justru diposisikan istimewa, terdidik, telah berbaur, dan hidup dalam suasana damai. Mereka telah menjadi bagian dari masyarakat Eropa atau Amerika yang diterima dengan menjalani gaya hidup sama seperti masyarakat Barat pada umumnya. Hubungan "cinta-benci" antara Barat dan Islam tengah menuju ke arah kompromi yang lebih menguntungkan. Banyak anggapan bahwa intervensi Barat terhadap yang lainnya itu masih dibutuhkan, tetapi tidak sedikit yang menganggap sekalipun intervensi itu dapat dibenarkan tetap saja telah terbukti malah menimbulkan bencana, dari 
mulai Afghanistan hingga ke Irak, bahkan Libya, Suriah, dan Yaman saat ini. Dialog secara tulus dan rasional, seharusnya menempati posisi penting saat ini, paling tidak dalam mengurai berbagai kebuntuan hubungan antara Barat dan Islam.

\section{Penutup}

Sejauh ini, berbagai relasi Barat-Islam masih diwarnai kecurigaan, mispersepsi, bahkan tak jarang memunculkan sentimen- sentimen tertentu yang terkait erat dengan keyakinan keagamaan. Seringkali, beberapa negara di bagian Selatan dengan mayoritas Kristen, para aktivisnya dan sebagian intelektualnya, masih memandang Islam sebagai "musuh" bagi mereka. Tidak hanya itu, terhadap minoritas Muslim yang ada di Barat, ungkapan-ungkapan yang ditujukan kepada Muslim seringkali merupakan kesalahpahaman dan bentuk ketidakdewasaan Barat dalam membangun suatu upaya dialog. Tariq Ramadan, sampai pada suatu kesimpulan, dimana alih-alih Barat menggali sumber- sumber peradaban mereka, mereka seringkali terjebak pada suatu pemahaman yang simplistik, dimana menguatnya Islam selalu dipandang dari sisi keagamaan akan terulangnya kembali masa-masa di abad Pertengahan, yang seolah menjadi saingan bagi mereka. ${ }^{1}$

Respon Islam terhadap modernitas dan counter terhadap sekularisasi yang datang dari Barat, memang disikapi secara berbeda-beda oleh beragam dunia Muslim. Isu-isu seputar ini-modernisasi, sekularisasi, dan kemudian demokrasi-yang kerap kali memunculkan sikap responsif Muslim yang pada tahap tertentu memang terdapat penolakan sama sekali terhadap ide-ide Barat ini. "Pemaksaan" ide-ide Barat melalui kolonisasinya telah memberikan kesan terhadap sebagian masyarakat Muslim, bahwa budaya mereka sedang diberangus, sehingga kemunculan reaksi keras umat Islam sulit dihindarkan. "Radikalisme muncul karena tekanan Barat terhadap dunia Muslim", demikian tulis Tariq Ramadan, sehingga tidak secara sederhana kemudian "radikalisme" kerap dihubungkan dengan Islam sebagai agama, padahal banyak faktor politik dan ekonomi yang menyebabkan ide-ide "keras" ini muncul.

Keruntuhan komunisme dan penerimaan dunia atas ide-ide modernisasi dan demokrasi Barat yang pernah dinyatakan sebagai "akhir dari sejarah" manusia (end of history) ternyata masih tetap menyimpan prasangka dimana Islam selalu menjadi "ancaman" bagi Barat dalam banyak hal. "Oh, East is East, and West is West, and never the twain shall meet", mungkin ini yang dibayangkan dalam benak Rudyard Kipling bahwa kedua peradaban "kembar" ini tidak mungkin dipertemukan, sebab memiliki latar historis yang sangat bertolak belakang. Barat tetaplah Barat dengan kesombongan peradabannya dan Timur tetap menjadi Timur dengan seperangkat peradabannya yang mengukir kemajuan peradaban dari Timur hingga Barat.

\section{Daftar Pustaka}

Amstrong, Karen. 2002. Islam: a Short History; Sepintas Sejarah Islam. Yogyakarta: Ikon Teralitera.Adisusilo, Sutarjo. (2002). Nasionalisme, Demokrasi, Civil Society. Jumal Iman, Ilmu, Budaya, III, (9): 4.

\footnotetext{
${ }^{1}$ Ramadan, dalam Munoz, Islam, hlm. 143 
Beck, H.L. \& N.J.G. Kaptein. 2001. Pandangan Barat Terhadap Literatur, Hukum, Filosofi, Teologi, dan Mistik Tradisi Islam. Jakarta: INIS

Blanks, David R \& Michael Frassetto (ed.). 1999. Western Views of Islam in Medieval and Early Modern Europe. New York: St Martin's Press

Dudireja, Adis dan Halim Rane. 2019. Islam and Muslims in the West: Major Issues and Debates, Switzerland: Palgrave Macmillan

Esposito, John L. Esposito. 2002. Unholy War: Terror in The Name of Islam. New York: Oxford University Hitti, Philip K. 1953. Dunia Arab: Sejarah Ringkas. Bandung: W. Van Hoeve

Hodgson, Marshall G.S. 1999. The Venture of Islam: Iman dan Sejarah dalam Peradaban Dunia, Buku Pertama. Jakarta: Paramadina Hatta, Mohammad, (1979). Memoir. Jakarta: Tintamas.

Huntington, Samuel. 2001. Benturan Antarperadaban dan Masa Depan Politik Dunia, Yogyakarta: Qalam

Husaini, Adian. "Bernard Lewis dan Apologia Barat" dalam Jurnal Tsaqafah. Vol 13, No.1, Mei 2017

Steenbrink, Karel. 1995. Kawan dalam Perikaian: Kaum Kolonial Belanda dan Islam di Indonesia. Bandung: Mizan

Lewis, Bernard. 1993. Islam and The West. New York: Oxford University Press

Tamara, M. Nasir dan Elza Peldi Taher. 1996. Agama dan Dialog Antar Peradaban. Jakarta: Paramadina

Munoz, Gema Martin. 1999. Islam, Modernism, and the West. New York: I.B. Tauris \& Co

Mutalib, Hussin. "Misunderstood Political Islam in Southeast Asia" dalam Harvard International Review. Vol. 28 No. 2, 2006

Putro, Suadi. 1998. Mohammed Arkoun Tentang Islam dan Modernitas. Jakarta: Paramadina

Rahman, Fazlur. 1982. Islam \& Modernity: Transformation of an Intellectual Tradition. London: The University of Chicago Press Ma'arif, Ahmad Syafii. (2009). Islam KeIndonesiaan dan Kemanusiaan: Sebuah Refleksi Sejarah. Bandung: Mizan.

Said, Edward W. 2002. Covering Islam: Bias Liputan Barat atas Dunia Islam. Yogyakarta: IkonTeralitera, Kebudayaan dan Kekuasaan: Membongkar Mitos Hegemoni Barat. 1995. Bandung: Mizan

Shamis, Ashur, "Islam and The West: Recognition, Reconciling, Co-Existence or Collision", dalam https://www.globalpolicyjournal.com/blog/20/06/2017/islam-and-westrecognitionreconciling-co-existence-or-collision, diakses 04 Juni 2020Majid, Abdul dan Swasono, Sri-Edi. (1988). Wawasan Ekonomi Pancasila. Jakarta: UI Press.

Tibi, Bassam. 2014. Political Islam, World Politics and Europe: from Jibadist to Institutional Islamism. New York: Routledge Narwoko, J Dwi, dan Suyanto, Bagong, ed. (2015) Sosiologi: Teks Pengantar dan Terapan. Jakarta: Prenada Media Group. 
MIMBAR Agama Budaya, 37 (1), 2020

Toguslu, Erkan, et al. 2014. New Multicultural Identities in Europe. Belgium: Louven University Pres

Watt, W. Montgomery. 1995. Islam dan Peradaban Dunia: Pengaruh Islam atas Eropa Abad Pertengahan. Jakarta: Gramedia 